\title{
The decreasing albedo of the Zhadang glacier on western Nyainqentanglha and the role of light-absorbing impurities
}

\author{
B. $\mathbf{Q u}^{4,1}$, J. Ming ${ }^{1,2,3}$, S.-C. Kang ${ }^{1,4}$, G.-S. Zhang ${ }^{4}$, Y.-W. Li ${ }^{4}$, C.-D. Li ${ }^{4}$, S.-Y. Zhao ${ }^{5}$, Z.-M. Ji ${ }^{4}$, and J.-J. Cao ${ }^{5}$ \\ ${ }^{1}$ State Key Laboratory of Cryospheric Sciences, Cold and Arid Regions Environmental and Engineering \\ Research Institute, Chinese Academy of Sciences, Lanzhou, China \\ ${ }^{2}$ Collaborative Innovation Centre on Forecast and Evaluation of Meteorological Disasters, Nanjing University of \\ Information Science \& Technology, Nanjing, China \\ ${ }^{3}$ National Climate Centre, China Meteorological Administration (CMA), Beijing, China \\ ${ }^{4}$ Key Laboratory of Tibetan Environment Changes and Land surface Processes, Institute of Tibetan Plateau \\ Research, Chinese Academy of Sciences, Beijing, China \\ ${ }^{5}$ State Key Laboratory of Loess and Quaternary Geology, Institute of Earth Environment, Chinese Academy \\ of Sciences, Xi'an, China
}

Correspondence to: J. Ming (petermingjing@ hotmail.com)

Received: 24 April 2014 - Published in Atmos. Chem. Phys. Discuss.: 21 May 2014

Revised: 14 September 2014 - Accepted: 16 September 2014 - Published: 22 October 2014

\begin{abstract}
A large change in albedo has a significant effect on glacier ablation. Atmospheric aerosols - e.g. black carbon (BC) and dust - can reduce the albedo of glaciers and thus contribute to their melting. In this study, two main themes were explored: (1) the decrease in albedo of the Zhadang glacier on Mt. Nyainqentanglha between 2001 and 2012, as observed by the Moderate Resolution Imaging Spectroradiometer (MODIS) on-board the Terra satellite, and the correlation of this albedo with mass balance; and (2) the concentrations of BC and dust in the glacier measured during 2012, and the associated impacts of these impurities on albedo and radiative forcings (RF). The average albedo of the Zhadang glacier from the MODIS increased with the altitude and fluctuated but had a decreasing trend $\left(-0.003 \mathrm{a}^{-1}\right)$ during the period 2001-2012, with the highest (0.722) in 2003 and the lowest (0.597) in 2009 and 2010. The mass balance of the glacier has a positively significant correlation with its surface albedo derived from MODIS. Snow samples were collected on the Zhadang glacier to measure the $\mathrm{BC}$ and dust in the summer of 2012. The impacts of BC and dust on albedo reduction in different melting conditions were identified with the SNow ICe Aerosol Radiative (SNICAR) model initiated by in situ observation data. The sensitivity analysis showed that $\mathrm{BC}$ was a major factor in albedo reduction when the glacier was covered by newly fallen snow. Never-
\end{abstract}

theless, the contribution of dust to albedo reduction can reach as high as $56 \%$, much exceeding that of BC ( $28 \%)$, when the glacier experiences strong surficial melting and its surface is almost bare ice. The average RF caused by dust could increase from 1.1 to $8.6 \mathrm{~W} \mathrm{~m}^{-2}$, exceeding the $\mathrm{RF}$ caused by $\mathrm{BC}$ after snow was deposited and surface melting occurred in the Zhadang glacier. This implies that it may be dust that primarily dominates the melting of some glaciers in the inner Tibetan Plateau during melting seasons, rather than BC.

\section{Introduction}

Glaciers and snow cover are important reservoirs of fresh water on Earth. A rough volume of $2.4 \times 10^{7} \mathrm{~km}^{3}$ of water is stored in them (Oki and Kanae, 2006), and changes in these reservoirs have a significant effect on the water supply in many regions of the world (Mote et al., 2003; Yao et al., 2012). The Tibetan Plateau (TP) is the source of many great rivers (e.g. Yangtze, Yellow, Indus, Ganges and Brahmaputra rivers), which concentrate their sources at the glaciers in the TP known as the "Asian Water Towers". More than 1.4 billion people depend on the water from these rivers (Immerzeel et al., 2010), but these glaciers have been undergoing rapid changes (Kang et al., 2010; Yao et al., 2012). Therefore, it 
is important to understand the impact factors that affect the glaciers and snow cover.

The surface energy budget of glaciers has significant effects on their ablation (Zhang et al., 2013), and snow/ice albedo is one of the most important parameters that affect the absorbed radiation. Snow/ice albedo is defined as the fraction of the reflected and the incident radiant flux in the surface of the snow/ice. A higher albedo implies a cleaner snow surface or less energy available for melting. Clean snow has the highest albedo (as high as 0.9) of any natural substance, but this diminishes when the snow surface is dirty or darkened due to snow grain size increases (Warren and Wiscombe, 1980; Wiscombe and Warren, 1980). A recent report (Lhermitte et al., 2012) indicates a darkening surface of the Greenland ice sheet and a rapidly decreasing albedo during 2000-2011, which will greatly increase the rate of mass loss of the ice sheet as more solar energy is absorbed by the darker glacial ice (Farmer and Cook, 2013).

Temperature, precipitation and glacial dynamic processes are the key factors that affect glacial change (Sugden and John, 1976). However, there is now a general consensus that light-absorbing constituents - LACs, e.g. black carbon (BC) and dust - can reduce the albedo of glaciers (dirtying or darkening effect) and thus also contribute to the mass loss of glaciers. Both BC and dust are important absorbers of solar radiation in the visible spectrum (Warren and Wiscombe, 1980; Hadley and Kirchstetter, 2012; IPCC, 2007), and BC has an absorbing capacity approximately 50 to 200 times greater than dust (Warren and Wiscombe, 1980). The impacts of BC and dust deposited on the TP glaciers (in particular, on their radiation balance) have been reported in previous literature (Xu et al., 2006, 2009a, 2012; Ming et al., 2009a, b, 2013a; Lau et al., 2010; Qian et al., 2011). Simulation of the effect of LACs on the albedo of Himalayan glaciers showed that LACs in this region had a contribution of $34 \%$ to the albedo reduction during the late spring time, with $21 \%$ due to $\mathrm{BC}$ and $13 \%$ originating from dust (Ming et al., 2012).

The lowering of the surface albedo due to the presence of a dust layer could also lead to a drastic increase in the glacier melting rate during the melting season (Fujita, 2007). In general, BC can be transported over long distances (Ming et al., 2010; Cao et al., 2010; Kopacz et al., 2011), whereas dust usually comes from the local or regional environment of the glaciers (Kang et al., 2000). Historical deposition records of $\mathrm{BC}$ revealed by ice cores and lake sediments over the TP indicate that $\mathrm{BC}$ originating from South and Central Asia has reached the glaciers in recent decades (Ming et al., 2008; Xu et al., 2009b; Cong et al., 2013; M. Wang et al., 2014).

There has been extensive research focusing on quantifying the impact of LACs in ice cores and snow cover to understand the relationship between LACs and albedo reduction (Aoki et al., 2011; Painter et al., 2007, 2012; Ginot et al., 2014; Kaspari et al., 2014). However, few researchers discussed the exact effects that BC and dust have on different types of glacier surfaces during the melting season. Dust sometimes causes significant spatial variation of the surface albedo in glaciers. Moreover, glacier melting causes LAC particles to concentrate in the surface and to further enhance the absorption of radiation. This positive feedback highlights the importance of investigating LACs and their effects on the albedo and glacial melt across a whole glacier, particularly in the background that the global glaciers are shrinking in general (IPCC, 2007) and the total BC emission is increasing (Bond et al., 2013).

The glaciers in the mid-Himalaya have been in general darkening since 2000 , which is partly attributed to the deposition of LACs, revealed by a previous study (Ming et al., 2012). The Zhadang glacier in the inner TP showed a mass balance of $-1500 \mathrm{~mm}$ water equivalent in 2005-2006 (Zhou et al., 2007), experiencing much stronger melting than Himalayan glaciers. Albedo and the factors inducing the variation of albedo are the "footstone" for understanding the dramatic change of the glaciers. Neither the long-term variation of the albedo of the Zhadang glacier, nor the impact of LACs on the albedo has been previously studied.

In this work, we will firstly investigate the albedo variation of the Zhadang glacier derived from the Moderate Resolution Imaging Spectroradiometer (MODIS) on-board the Terra satellite from 2001 through 2012, and then discuss the spatial distribution of LACs from the termination along to the accumulation zone of the Zhadang glacier during the summer of 2012, and then estimate the contribution of BC and dust to the albedo reduction in different melting conditions by simulations.

\section{Methodology}

The Zhadang glacier is located in western Nyainqentanglha, southern TP, $\left(30^{\circ} 28.57^{\prime} \mathrm{N}, 90^{\circ} 38.71^{\prime} \mathrm{E}\right.$, and $5500-5800 \mathrm{~m}$ a.s.1.) (Fig. 1). Surface snow/ice samples were collected, and the surface albedo was observed on the Zhadang glacier during 12-16 July and 24-27 August 2012. The observation of surface mass balance on the Zhadang glacier has been conducted by the traditional stake method since late 2005 (Zhou et al., 2007).

We classified three conditions or scenarios of the glacier surface: (1) S-I: the surface of the glacier is bare ice containing some visible dark constituents (Fig. 2a); (2) S-II: the surface is covered by aged snow/firn (Fig. 2a); (3) S-III: the surface is covered by fresh snow (Fig. 2b). These surface conditions are typical in most alpine glaciers throughout the year (Benn and Evans, 2010). A description of the sampling details in the Zhadang glacier is given in Table 1.

\subsection{Albedo data from the MODIS}

The MODIS albedo data were used to investigate the albedo change in the Zhadang glacier. The series of the product is the MODIS/Terra Snow Cover Daily L3 Global 500 m Grid 


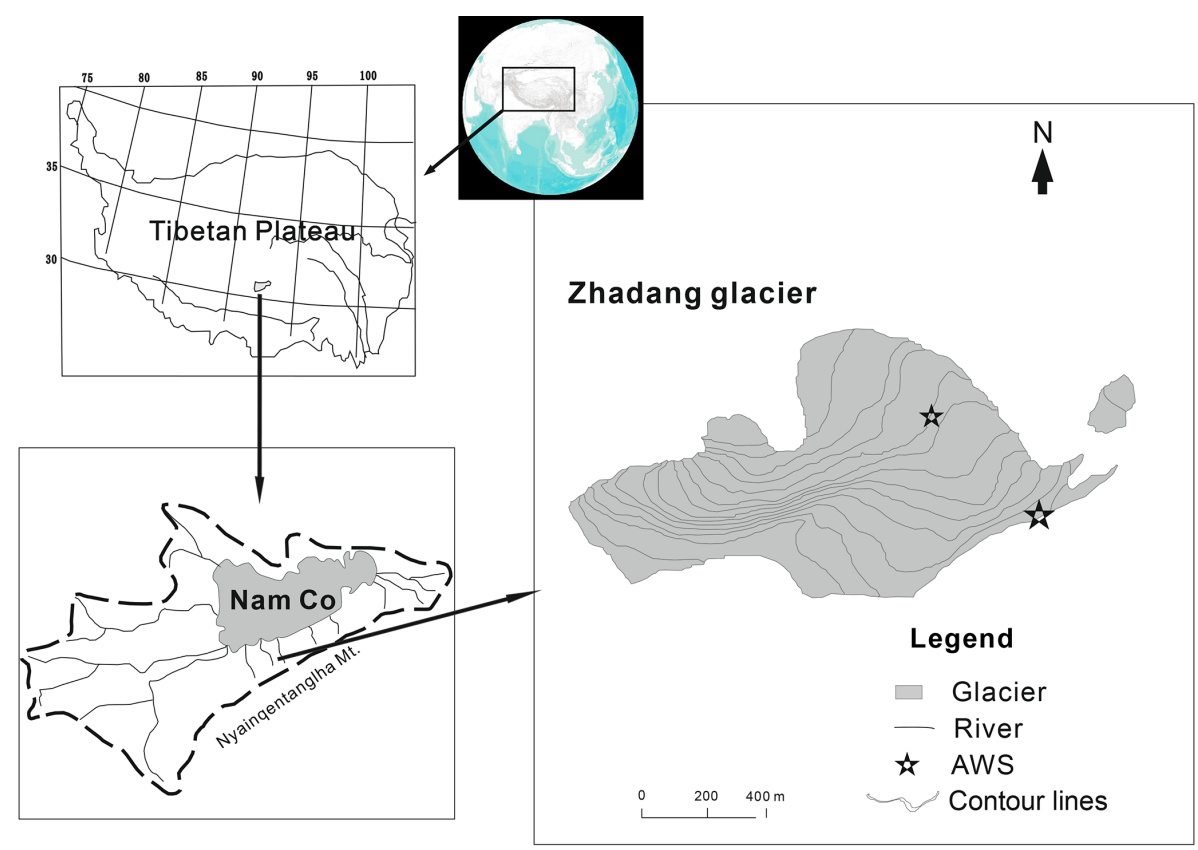

Figure 1. Location of the Zhadang glacier on Mt Nyainqentanglha.

Table 1. Sampling information: two expeditions were conducted on the Zhadang glacier, and samples (albedo, snow/ice) were collected under three melting conditions of the glacier in July and August of 2012. We measured the albedo five to six times at each site whilst collecting two to three snow/ice samples. In total, 120 albedo measurements and 48 snow/ice samples were obtained at the A-D sample sites in July 2012 for the S-I and S-II conditions (Fig. 2). A total of 160 albedo samples and 64 snow samples were obtained at all sampling sites in August 2012. The albedo and concentrations of BC and dust are listed here.

\begin{tabular}{|c|c|c|c|c|c|c|c|c|c|c|c|c|}
\hline $\begin{array}{l}\text { Sample } \\
\text { date }\end{array}$ & $\begin{array}{l}\text { Sample } \\
\text { site }\end{array}$ & $\begin{array}{r}\text { Altitude } \\
\text { (m a.s.1.) }\end{array}$ & $\begin{array}{r}\text { No. of samples } \\
\text { (albedo/ } \\
\text { snow \& ice) }\end{array}$ & $\begin{array}{r}\text { Average of } \\
\text { albedo }\end{array}$ & $\begin{array}{r}\text { Average of } \mathrm{BC} \\
\text { conc. }(\mathrm{ppb})\end{array}$ & $\begin{array}{r}\text { Average of dust } \\
\text { conc. (ppm) }\end{array}$ & $\begin{array}{r}\text { Snow grain } \\
\text { size }(\mathrm{mm}) \\
\left(\mathrm{kg} \mathrm{m}^{-3}\right)\end{array}$ & $\begin{array}{r}\text { Snowpack } \\
\text { density } \\
(\mathrm{cm})\end{array}$ & $\begin{array}{l}\text { Snowpack } \\
\text { Thickness }\end{array}$ & $\begin{array}{r}\text { Solar zenith } \\
\text { angle }\left(^{\circ}\right)\end{array}$ & $\begin{array}{r}\text { Cloud amount } \\
(10=100 \%)\end{array}$ & $\begin{array}{r}\text { Scene } \\
\text { type }\end{array}$ \\
\hline \multirow{4}{*}{$\begin{array}{l}\text { July } \\
2012\end{array}$} & A & 5507 & $30 / 12$ & 0.385 & 472.6 & 503.8 & $0.8-1.6$ & $289-380$ & 1 & $44.8-78.9$ & $3-10$ & \multirow{2}{*}{ S-I } \\
\hline & B & 5680 & $30 / 12$ & 0.521 & 334.4 & 1891.9 & $0.6-1.6$ & $289-350$ & $1-2$ & $52.3-75.8$ & $1-10$ & \\
\hline & $\mathrm{C}$ & 5720 & $30 / 12$ & 0.676 & 142.9 & 66.6 & $0.4-0.7$ & $333-378$ & $2-3$ & $62.9-79.1$ & $1-10$ & \multirow{2}{*}{ S-II } \\
\hline & D & 5795 & $30 / 12$ & 0.686 & 80.9 & 33.6 & $0.3-0.5$ & $267-289$ & 3 & $67.1-67.3$ & $0-10$ & \\
\hline \multirow{8}{*}{$\begin{array}{l}\text { August } \\
2012\end{array}$} & A & 5507 & $20 / 8$ & 0.589 & 53.2 & 8.2 & $0.2-0.5$ & $278-300$ & $1-2$ & $33.4-44$ & $0-10$ & \multirow{8}{*}{ S-III } \\
\hline & B & 5560 & $20 / 8$ & 0.696 & 40.8 & 8.0 & $0.2-0.4$ & $256-289$ & $2-3$ & $37.6-47.1$ & $1-7$ & \\
\hline & $\mathrm{C}$ & 5626 & $20 / 8$ & 0.710 & 55.5 & 7.0 & $0.2-0.4$ & $267-311$ & $2-3$ & $40.8-50.2$ & $0-7$ & \\
\hline & D & 5680 & $20 / 8$ & 0.699 & 52.7 & 6.7 & $0.2-0.4$ & $267-289$ & 3 & $43.8-54.1$ & $1-8$ & \\
\hline & $\mathrm{E}$ & 5695 & $20 / 8$ & 0.708 & 55.2 & 6.4 & $0.2-0.4$ & $267-289$ & $3-4$ & $45.8-57.9$ & $0-6$ & \\
\hline & $\mathrm{F}$ & 5715 & $20 / 8$ & 0.667 & 57.7 & 6.2 & $0.2-0.4$ & $278-289$ & 4 & $49.9-61.4$ & $0-7$ & \\
\hline & G & 5750 & $20 / 8$ & 0.698 & 59.4 & 5.2 & $0.2-0.3$ & $222-244$ & 5 & $51.9-64.6$ & $0-7$ & \\
\hline & $\mathrm{H}$ & 5795 & $20 / 8$ & 0.724 & 40.9 & 3.4 & $0.2-0.3$ & $211-222$ & 5 & $61.2-68.4$ & $0-10$ & \\
\hline
\end{tabular}

(MOD10A1), which is based on a snow mapping algorithm that employs a normalised difference snow index (NDSI) and other criteria tests (Riggs and Hall, 2011). The MOD10A1 product contains four data layers: snow cover, snow albedo, fractional snow cover and binary quality assessment (QA), which is assigned as "good" or "bad". The data are compressed in the hierarchical data format Earth observing system (HDF-EOS) and are formatted along with the corresponding metadata. The images of MOD10A1 are $1200 \mathrm{~km}$ by $1200 \mathrm{~km}$ tiles with a resolution of $500 \mathrm{~m} \times 500 \mathrm{~m}$ gridded in a sinusoidal map projection. Data are available from 24 February 2000 to the present via FTP (Hall et al., 2006). The snow albedo data used in the calculation are based on three expected criteria: the pixels are identified as snow cover, fractional snow cover is 100 , and the pixels pass the QA. The MODIS daily albedo has high accuracy in flat terrain (Stroeve et al., 2006; Tekeli et al., 2006), but it shows some errors in complex topography, such as mountainous regions (Sorman et al., 2007; Warren, 2013).

To verify the applicability of the MOD10A1 product in the Zhadang glacier, we used the observed data measured by the Kipp and Zonen radiometers mounted on an automatic weather station (AWS) that was set in the saddle of the glacier (5680 $\mathrm{m}$ a.s.l., Fig. 1). The albedo data were extracted from the precise pixel in the relevant MODIS image where the AWS was located. The observed albedos were selected 
in the local time period of 12:30 to 13:30 LT, considering the scanning time of the Terra satellite passing over the study area. The correlation analysis between the MODIS data and the observed data showed a good relationship at the confidence level of 0.02 (Fig. 3), indicating that it is reasonable to use MOD10A1 data to study the albedo change of the Zhadang glacier.

\subsection{Field albedo observation}

Warren (2013) suggested that it is unlikely to detect the impact of $\mathrm{BC}$ on snow albedo by remote sensing. In this work, a spectroradiometer (Model ASD ${ }^{\circledR}$ FS-3) was used to measure the spectral albedo of the glacier. This covers a radiation waveband of $350-2500 \mathrm{~nm}$ with a wavelength resolution of one nanometre. The optical sensor of the spectroradiometer was set in a pistol-shape device so that the optical fibre can be fixed inside and mounted on the rocker arm of the tripod with a gradienter for levelling. The distance between the sensor and the snow surface was approximately $0.5 \mathrm{~m}$, allowing for the measurement of the spectral reflectances. Air temperature has been recorded by an autonomous weather station (AWS) built up in the accumulative zone of the Zhadang glacier since 2008 (Fig. 1).

During the expedition of July 2012, we measured the surface albedo and collected snow samples in S-I (two sites: A and B) and S-II (C and D) conditions. In August, the glacier was covered by newly fallen snow, and the albedo and surface snow samples were successfully observed and collected at eight sites in S-III conditions (Fig. 2). Along with the sampling, other necessary parameters, such as snow density, and grain sizes, for simulating the surface albedo were also observed. Details concerning the simulations of the surface albedo have been introduced in a previous work (Ming et al., 2013a).

\subsection{Snow/ice sampling and $\mathrm{BC} /$ dust measurement}

Snow/ice samples were collected in accordance with the "Clean Hands - Dirty Hands" principle, meaning that the person whose hands are collecting sampling will not touch any other material that may contaminate the snow samples (Fitzgerald, 1999). We collected two parallel samples $10 \mathrm{~cm}$ away from each other from the surface to $5 \mathrm{~cm}$ depth at each site when measuring the albedo. The snow density was measured using a balance. The samples were stored in NALGENE ${ }^{\circledR}$ HDPE wide-mouth bottles $(250 \mathrm{~mL})$ and were kept frozen until laboratory analysis. The snow grain sizes were measured using a hand lens $(25 \times)$ with an accuracy of $0.02 \mathrm{~mm}$; the largest length of a single ice crystal was also measured using a snow crystal card with $1 \mathrm{~mm}$ grids (Aoki et al., 2007). We filtered the snow melt water through quartz-fibre filters, which were weighed before and after the filtration using a microbalance to evaluate the mass of onload dust. A thermal-optical method of carbon analysis, us-

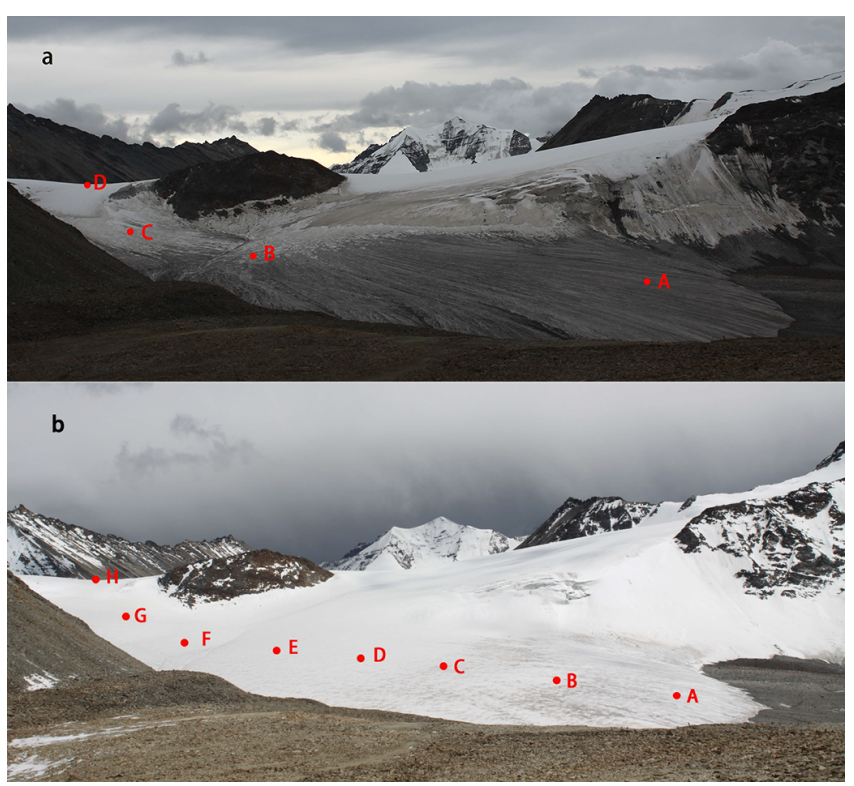

Figure 2. Surface features of the Zhadang glacier on 16 July (a) and 26 August (b). The two surface conditions include three types of melting conditions: S-I: sites A and B, which are located in the superimposed ice belt (Fig. 2a); S-II: sites C and D, which are in the upper area of the glacier (Fig. 2a); S-III: all sites were covered by fresh snow (Fig. 2b).

ing DRI ${ }^{\circledR}$ Model 2001A OC/EC (Chow et al., 1993), was employed to measure the $\mathrm{BC}$ mass in the samples.

\subsection{Albedo reduction modelling and radiative forcing (RF)}

The Snow-Ice-Aerosol-Radiative (SNICAR) model can be used to simulate the hemisphere albedo of snow and ice for unique combinations of impurity contents (BC, dust and volcanic ash), snow grain size and incident solar flux characteristics (Flanner et al., 2007). It was applied to simulate the albedo variation caused by $\mathrm{BC}$ and dust deposited in the glacier surface in this work. We conducted a series of sensitivity analyses to identify the impact of $\mathrm{BC}$ and dust on albedo reduction in three different surface conditions of the Zhadang glacier (also see Sect. 2.2). The solar zenith angle was identified based on the time and position of the specific sampling sites. The snow grain effective radius is taken as half the observed snow grain size introduced by Aoki et al. (2007) and is shown in Table 1. The albedo of the underlying bare ice is taken as $0.11-0.19$ in the visible band and $0.18-0.23$ in the near-infrared band as measured in situ by the spectroradiometer. We use the default value 1 as the mass absorption cross-section (MAC) scaling factor (experimental) in the modelling. The detailed parameters used in SNICAR are listed in Appendix A. 


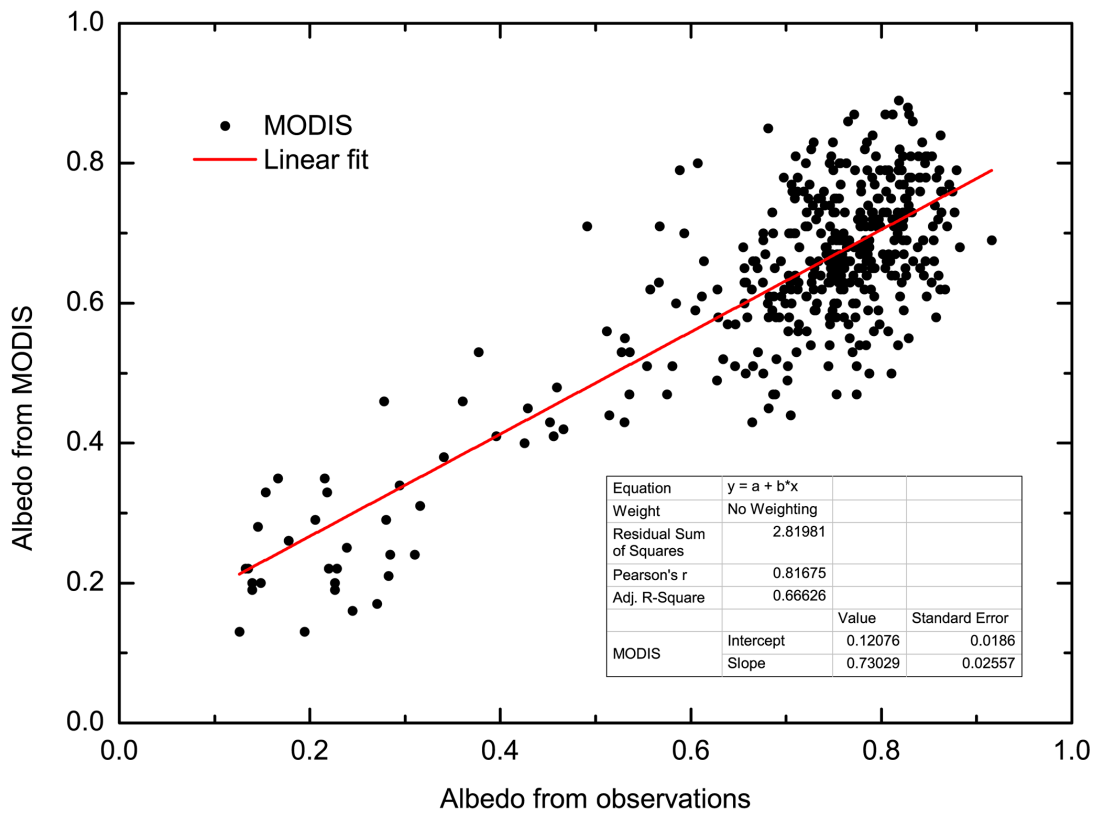

Figure 3. The albedo of the pixel including the AWS in Zhadang glacier derived from MODIS and that observed by AWS in 2011.

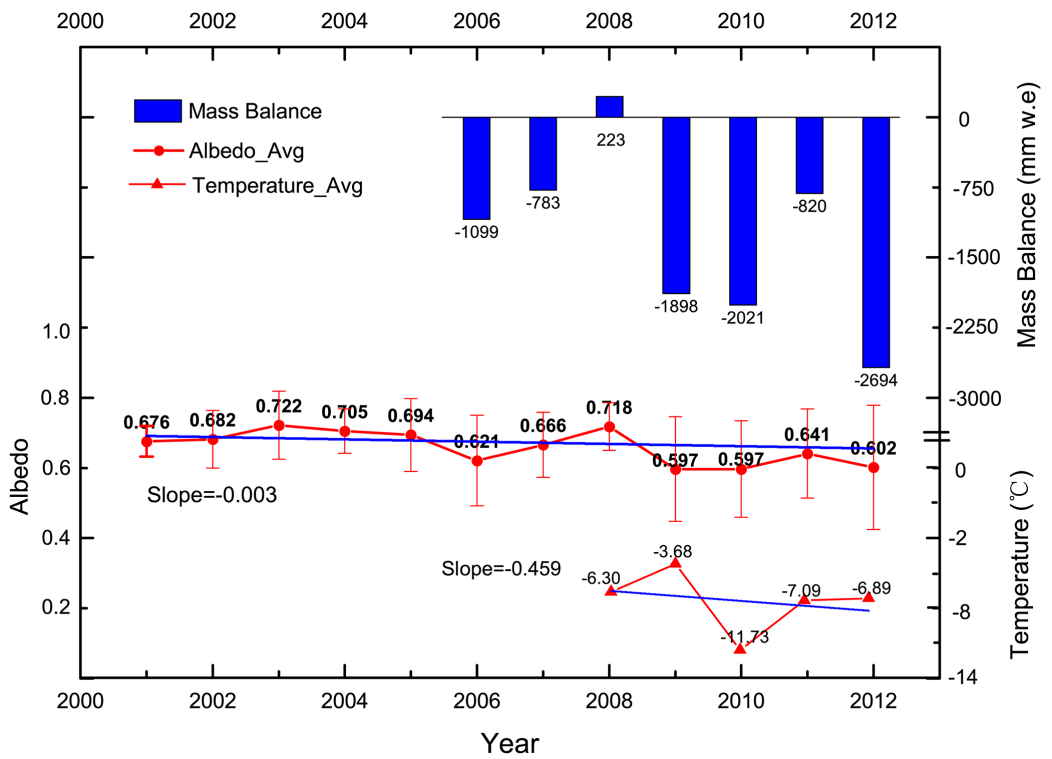

Figure 4. Temporal changes of the albedo in the Zhadang glacier from 2001 to 2012 and the mass balance from 2006 to 2012 . The albedo of the Zhadang glacier showed an overall downward trend in the last decade. Air temperature recorded by an AWS in the Zhadang glacier shows a slight decreasing trend.

RF was defined as

$\mathrm{RF}=R_{\text {in-short }} \cdot \Delta \alpha$

where $R_{\text {in-short }}$ denotes the incident solar radiation measured by radiometer and $\Delta \alpha$ denotes the reduction of the albedo.

\section{Results and discussion}

\subsection{Surface albedo variations of the Zhadang glacier during the period 2001-2012}

The albedo of the Zhadang glacier increased with elevation (Table 1) due to the lower temperature favouring more cold snow stored in higher elevations. The annual average albedo from the MODIS decreased from 0.676 in 2001 to 
Table 2. Sensitivity analysis with the SNICAR model. BC \% and Dust \% are the contributions of BC and dust to the total reduction of the albedo, respectively. $R_{\text {in-short }}$ is the incident solar radiation measured by AWS.

\begin{tabular}{|c|c|c|c|c|c|c|c|c|c|c|c|}
\hline Date & Site & $\mathrm{OA}$ & $\begin{array}{r}\text { SA } \\
\text { pure }\end{array}$ & $\mathrm{SA}+\mathrm{BC}$ & $\begin{array}{r}\mathrm{SA}+\mathrm{BC} \\
\text { and dust }\end{array}$ & BC $\%$ & Dust \% & $R_{\text {in-short }}$ & $\mathrm{RF}+\mathrm{BC}$ & $\begin{array}{r}\mathrm{RF}+\text { dust } \\
\text { type }\end{array}$ & Scene \\
\hline $15 \mathrm{Jul}$ & A & 0.385 & 0.406 & 0.395 & 0.388 & 52 & 33 & 780.1 & 8.6 & 5.5 & \multirow{4}{*}{ S-I } \\
\hline $16 \mathrm{Jul}$ & A & 0.387 & 0.413 & 0.405 & 0.396 & 31 & 34 & 412.6 & 3.3 & 3.7 & \\
\hline $15 \mathrm{Jul}$ & B & 0.363 & 0.406 & 0.394 & 0.364 & 28 & 70 & 548.2 & 6.6 & 16.4 & \\
\hline $16 \mathrm{Jul}$ & B & 0.558 & 0.577 & 0.576 & 0.560 & 4 & 85 & 535.3 & 0.4 & 8.6 & \\
\hline 14 Jul & $\mathrm{C}$ & 0.618 & 0.640 & 0.631 & 0.624 & 41 & 32 & 1308.5 & 11.8 & 9.2 & \multirow{6}{*}{ S-II } \\
\hline $15 \mathrm{Jul}$ & $\mathrm{C}$ & 0.723 & 0.758 & 0.742 & 0.727 & 46 & 43 & 543.7 & 8.7 & 8.2 & \\
\hline $16 \mathrm{Jul}$ & $\mathrm{C}$ & 0.745 & 0.756 & 0.754 & 0.752 & 18 & 18 & 604.4 & 1.2 & 1.2 & \\
\hline 14 Jul & $\mathrm{D}$ & 0.745 & 0.771 & 0.760 & 0.753 & 42 & 27 & 552.7 & 6.1 & 3.9 & \\
\hline $15 \mathrm{Jul}$ & $\mathrm{D}$ & 0.732 & 0.754 & 0.745 & 0.740 & 41 & 23 & 648.4 & 5.8 & 3.2 & \\
\hline $16 \mathrm{Jul}$ & $\mathrm{D}$ & 0.755 & 0.775 & 0.770 & 0.764 & 25 & 30 & 789.8 & 3.9 & 4.7 & \\
\hline 24 Aug & A & 0.568 & 0.791 & 0.786 & 0.784 & 2 & 1 & 337.8 & 1.4 & 0.7 & \multirow{22}{*}{ S-III } \\
\hline $25 \mathrm{Aug}$ & A & 0.653 & 0.682 & 0.681 & 0.680 & 5 & 2 & 658.7 & 0.9 & 0.5 & \\
\hline $26 \mathrm{Aug}$ & A & 0.716 & 0.746 & 0.739 & 0.737 & 23 & 7 & 702.5 & 4.9 & 1.4 & \\
\hline 24 Aug & B & 0.759 & 0.793 & 0.779 & 0.778 & 41 & 4 & 608.1 & 8.5 & 0.9 & \\
\hline $25 \mathrm{Aug}$ & $\mathrm{B}$ & 0.696 & 0.731 & 0.728 & 0.727 & 8 & 4 & 722.7 & 1.9 & 0.9 & \\
\hline $26 \mathrm{Aug}$ & $\mathrm{B}$ & 0.656 & 0.683 & 0.681 & 0.68 & 7 & 4 & 736.2 & 1.5 & 0.7 & \\
\hline 26 Aug & $\mathrm{C}$ & 0.697 & 0.734 & 0.732 & 0.732 & 5 & 1 & 776.8 & 1.6 & 0.3 & \\
\hline 24 Aug & $\mathrm{D}$ & 0.726 & 0.806 & 0.797 & 0.795 & 11 & 3 & 822.6 & 7.4 & 1.6 & \\
\hline $25 \mathrm{Aug}$ & $\mathrm{D}$ & 0.768 & 0.781 & 0.780 & 0.778 & 17 & 10 & 814 & 1.8 & 1.1 & \\
\hline 26 Aug & $\mathrm{D}$ & 0.647 & 0.781 & 0.779 & 0.778 & 1 & 1 & 811 & 1.3 & 1.0 & \\
\hline 24 Aug & $\mathrm{E}$ & 0.699 & 0.810 & 0.803 & 0.802 & 6 & 1 & 962 & 6.7 & 1.0 & \\
\hline 25 Aug & $\mathrm{E}$ & 0.780 & 0.813 & 0.809 & 0.807 & 12 & 6 & 891.5 & 3.6 & 1.8 & \\
\hline $26 \mathrm{Aug}$ & $\mathrm{E}$ & 0.774 & 0.811 & 0.805 & 0.804 & 16 & 3 & 831 & 5.0 & 1.0 & \\
\hline 24 Aug & $\mathrm{F}$ & 0.792 & 0.839 & 0.835 & 0.833 & 9 & 4 & 786.8 & 3.1 & 1.6 & \\
\hline $25 \mathrm{Aug}$ & $\mathrm{F}$ & 0.790 & 0.819 & 0.816 & 0.815 & 10 & 3 & 1030 & 3.1 & 1.0 & \\
\hline $26 \mathrm{Aug}$ & $\mathrm{F}$ & 0.566 & 0.816 & 0.809 & 0.808 & 3 & 1 & 895 & 6.0 & 1.2 & \\
\hline 24 Aug & $\mathrm{G}$ & 0.795 & 0.848 & 0.840 & 0.838 & 15 & 4 & 1303 & 10.4 & 2.6 & \\
\hline $25 \mathrm{Aug}$ & G & 0.806 & 0.828 & 0.824 & 0.823 & 18 & 5 & 1168 & 4.7 & 1.2 & \\
\hline 26 Aug & G & 0.652 & 0.819 & 0.812 & 0.811 & 4 & 1 & 932 & 6.5 & 0.9 & \\
\hline 24 Aug & $\mathrm{H}$ & 0.811 & 0.853 & 0.846 & 0.846 & 16 & 1 & 1134 & 7.5 & 0.6 & \\
\hline $25 \mathrm{Aug}$ & $\mathrm{H}$ & 0.809 & 0.834 & 0.831 & 0.830 & 12 & 4 & 1316 & 3.9 & 1.3 & \\
\hline $26 \mathrm{Aug}$ & $\mathrm{H}$ & 0.711 & 0.827 & 0.825 & 0.824 & 2 & 1 & 1192 & 2.4 & 1.2 & \\
\hline Avg. & S-I,II,III & 0.684 & 0.741 & 0.735 & 0.731 & 18 & 15 & 826.1 & 4.7 & 2.8 & \\
\hline
\end{tabular}

Note: OA denotes observed albedo, SA denotes simulated albedo.

0.597 in 2010 with a maximum of 0.722 in 2003 and a minimum of 0.597 in 2009 and 2010. The albedo of the Zhadang glacier shows an obvious decreasing trend of $0.003 \mathrm{a}^{-1}$ during the period 2001-2012, despite the inter-annual fluctuations (Fig. 4). This trend was also revealed in the Himalayan and Tanggula glaciers (Ming et al., 2012; Wang et al., 2012). Regional air temperature shows a decreasing trend during the period 2008-2012, which seems not to be the cause of the albedo decreasing (Fig. 4), implying that other factors could induce the varying.

The surface albedo of a specific glacier could be linked with its mass balance in the TP, which has been proved by J. Wang et al. (2014). We used the observed mass balance data from 2006 through 2012 in the Zhadang glacier (Zhou et al., 2007; Zhang et al., 2013) to perform a correlation analysis with the glacier surface albedo (Fig. 4). Lower albedos are related to more negative mass balances, and vice versa. For example, the most negative mass balance appeared in 2010 when the albedo reached the minimum, whereas the most positive mass balance occurred in 2008, and the albedo was also the highest. The significant positive correlation $(n=7$, $\alpha=0.01, R^{2}>0.83$ ) between the albedo and the mass balance of the glacier implies that surface albedo is a strong index of the mass balance for the glacier. 


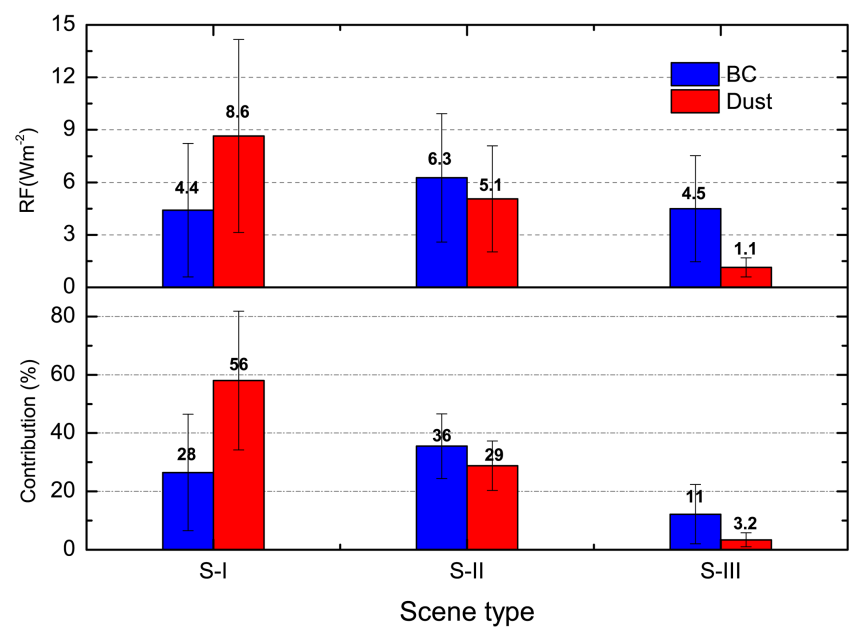

Figure 5. Mid-day RFs of BC and dust on the Zhadang glacier and the contribution (results from the SNICAR model) show the reduction of the albedo in the surface snow cover area under three different melting conditions: S-I, where the surface of the glacier is bare ice; S-II, where the glacier is covered by aged snow; S-III, where the glacier is covered by fresh snow. Error bars show the uncertainties.

\subsection{Impacts of $\mathrm{BC}$ and dust on the albedo}

A previous study conducted at a site approximately $20 \mathrm{~km}$ northeast of the Zhadang glacier indicated that the BC concentration showed an increasing trend during the period 2006-2010 (Zhao et al., 2013), which allows one to presume the possibly increasing deposition of $\mathrm{BC}$ in the glacier surface, enhancing the surficial radiation absorption and decreasing the albedo. Thus taking LACs into consideration, and sampling and measuring their concentrations, is a reasonable approach for interpreting the albedo decrease revealed by the MODIS data.

The measurements of $\mathrm{BC}$ and dust concentrations, as well as other observations such as snow grain size, snowpack density and snowpack thickness on the Zhadang glacier are shown in Table 1. In S-I conditions, the concentration of dust varied from 504 to 1892 with an average of 1198 ppm, whereas BC was 334-473 with an average of $404 \mathrm{ppb}$. In SII conditions, the concentrations of $\mathrm{BC}$ and dust ranged from 81 to 143 with an average of $112 \mathrm{ppb}$ and from 34 to 67 with an average of $50 \mathrm{ppm}$, respectively. However, the concentration of BC in S-III was 41 to 59 with an average of $52 \mathrm{ppb}$, whereas the dust concentration was 3 to 8 with an average of $6 \mathrm{ppm}$.

There are large differences in the $\mathrm{BC}$ and dust concentrations in the surface of the Zhadang glacier in different scenarios of surface features (Fig. 2a). In S-I and S-II, intensive surface melting could lead to a strong enrichment of LACs in the surface of the glacier. In S-III conditions, the Zhadang glacier was covered by fresh snow due to frequent snowfalls at night (Fig. 2b). Thus, the concentrations of LACs in S-III are several magnitudes lower than those in S-I and S-II conditions (Table 1). Table 2 provides observed and simulated albedos at the sampling sites. The observed surface albedo increases roughly along with the elevation on the Zhadang glacier, in contrast with the concentrations of BC and dust in S-I and S-II conditions. The correlations of in situ observed albedo and the albedo simulated by SNICAR after adding measured BC and dust into the snow surface are 0.9992 for S-I, 0.9995 for S-II, and 0.4729 for S-III, respectively. This implies that the enrichment of BC and dust on the surface of the glacier could reduce the glacier albedo, thus resulting in the melting of glaciers.

The sensitivity analysis of the respective impacts of $\mathrm{BC}$ and dust on reducing the snow albedo of the Zhadang glacier was calculated by SNICAR and is shown in Fig. 5. We assume that the model also works well for thin snow $(<5 \mathrm{~cm})$ with ice beneath. This configuration with the SNICAR model implies that impurities contained within the ice beneath the snow do not contribute to the RF calculations. It is unclear how important this assumption is, but it may contribute to a low bias in the RF estimates. We presume three impacting factors dominating the albedo varying in the glacial surface, i.e. $\mathrm{BC}$, dust, and the grain size growing due to warming (Ming et al., 2012). Dust exceeding BC was the most dominant factor in reducing glacier albedo in S-I. BC other than dust dominates albedo reduction in cases where the glacier was covered by snow (S-II and S-III). The incoming solar irradiances at every sampling time during the two trips are listed in Table 2.

We calculated the RF of both $\mathrm{BC}$ and dust on the Zhadang glacier. The simulation shows that the RF caused by BC and dust deposition on the Zhadang glacier varied between 0.4$11.8 \mathrm{~W} \mathrm{~m}^{-2}$ and $0.5-16.4 \mathrm{~W} \mathrm{~m}^{-2}$, respectively (Fig. 5). The $\mathrm{RF}$ of dust is much higher than that of BC in S-I, whereas the RF of BC exceeds dust in S-II and S-III. On average, the forcing caused by dust deposition on the Zhadang glacier in the summer of 2012 was $2.7 \pm 3.4 \mathrm{~W} \mathrm{~m}^{-2}$, and that caused by $\mathrm{BC}$ was $4.8 \pm 3.2 \mathrm{~W} \mathrm{~m}^{-2}$, which is lower than that reported in the northern TP (Ming et al., 2013b) and higher than reported in the Arctic (Wang et al., 2011; Flanner, 2013; Dou et al., 2012). Lacking long-term measurements of LACs in the Zhadang glacier makes directly evaluating the impacts of LACs on the albedo decreasing in 2001-2012 impossible, whereas the investigation in 2012 presented a possible interpretation that the LACs could decrease the surface albedo, taking into consideration the increasing of $\mathrm{BC}$ concentration in the surrounding atmosphere (Zhao et al., 2013).

\section{Summary and conclusions}

The albedo of the Zhadang glacier decreased at the rate of $-0.003 \mathrm{a}^{-1}$ throughout the period 2001 to 2012 , according to the MODIS data. The variation of albedo had a positively significant correlation with the mass-balance variation 
in 2006-2012, implying that remotely sensed albedo can be used as an indicating index of the mass balance of the glacier. The deposition of LACs may cause the decreasing of albedo in the Zhadang glacier while the surface temperature showed a decreasing trend. During the summer of 2012, the average concentrations of BC and dust were $404 \mathrm{ppb}$ and $1198 \mathrm{ppm}$ in the surface, which are 1 and 3 magnitudes higher than the $52 \mathrm{ppb}$ of $\mathrm{BC}$ and the $6.4 \mathrm{ppm}$ of dust in fresh snow of the Zhadang glacier. The impacts of $\mathrm{BC}$ and dust on the glacier albedo were quantified based on the observations and simulation. The contribution of dust and $\mathrm{BC}$ to albedo reduction was 56 and $28 \%$, respectively, when the glacier was covered by bare ice. In the surface covered by aged snow, $36 \%$ of the surface albedo reduction was caused by BC, and $29 \%$ by dust. When the glacier was covered by fresh snow, BC and dust contributed 11 and $3 \%$ to albedo reduction, respectively. In general, $\mathrm{BC}$ is a major factor in albedo reduction when the glacier is covered by fresh and aged snow; however, dust makes the most significant contribution to albedo reduction when the surface of the glacier is bare ice. 
Appendix A: Parameters for sensitivity analysis with SNICAR

Table A1. 1. Incident radiation (a. Direct, b. Diffuse); 2. Solar zenith angle; 3. Surface spectral distribution (a. Mid-latitude winter, clear-sky, cloud amount $<5$. b. Mid-latitude winter, cloudy, cloud amount $\geq 5) ; 4$. Snow grain effective radius $(\mu m) ; 5$. Snowpack thickness $(\mathrm{m}) ; 6$. Snowpack density $\left(\mathrm{kg} \mathrm{m}^{-3}\right)$; 7. Albedo of underlying ground (a. Visible, 0.3-0.7 $\mu \mathrm{m}$. b. Near-infrared, 0.7-5.0 $\left.\mu \mathrm{m}\right)$; 8. MAC scaling factor (experimental) for BC; 9. BC concentration (ppb, Sulfate-coated); 10. Dust concentration (ppm, 5.0-10.0 $\mu$ m diameter); 11. Volcanic ash concentration (ppm); 12. Experimental particle 1 concentration (ppb).

\begin{tabular}{|c|c|c|c|c|c|c|c|c|c|c|c|c|c|c|}
\hline Date & site & 1 & 2 & 3 & 4 & 5 & 6 & $7 a$ & $7 b$ & 8 & 9 & 10 & 11 & 12 \\
\hline $14 \mathrm{Jul}$ & $\mathrm{C}$ & b & 79.1 & b & 600 & 0.02 & 378 & 0.15 & 0.3 & 1 & 129.9 & 56.4 & 0 & 0 \\
\hline $14 \mathrm{Jul}$ & $\mathrm{D}$ & $\mathrm{b}$ & 67.3 & $\mathrm{~b}$ & 400 & 0.05 & 289 & 0.15 & 0.3 & 1 & 77.2 & 29.6 & 0 & 0 \\
\hline $15 \mathrm{Jul}$ & A & $\mathrm{b}$ & 78.9 & $\mathrm{~b}$ & 800 & 0.01 & 289 & 0.13 & 0.12 & 1 & 608.2 & 649.3 & 0 & 0 \\
\hline $15 \mathrm{Jul}$ & B & $\mathrm{b}$ & 75.8 & b & 800 & 0.01 & 289 & 0.13 & 0.12 & 1 & 657.3 & 3628.8 & 0 & 0 \\
\hline $15 \mathrm{Jul}$ & $\mathrm{C}$ & a & 71.6 & a & 400 & 0.02 & 367 & 0.15 & 0.3 & 1 & 278 & 135.1 & 0 & 0 \\
\hline $15 \mathrm{Jul}$ & $\mathrm{D}$ & $\mathrm{a}$ & 67.2 & $\mathrm{a}$ & 400 & 0.03 & 278 & 0.15 & 0.3 & 1 & 114 & 39 & 0 & 0 \\
\hline $16 \mathrm{Jul}$ & A & $\mathrm{a}$ & 44.8 & $\mathrm{a}$ & 700 & 0.01 & 380 & 0.13 & 0.12 & 1 & 337 & 358.3 & 0 & 0 \\
\hline $16 \mathrm{Jul}$ & B & $\mathrm{a}$ & 52.3 & $\mathrm{a}$ & 700 & 0.02 & 350 & 0.15 & 0.3 & 1 & 11.5 & 155 & 0 & 0 \\
\hline $16 \mathrm{Jul}$ & $\mathrm{C}$ & $\mathrm{a}$ & 62.9 & $\mathrm{~b}$ & 400 & 0.03 & 333 & 0.15 & 0.3 & 1 & 20.8 & 8.3 & 0 & 0 \\
\hline $16 \mathrm{Jul}$ & $\mathrm{D}$ & $\mathrm{a}$ & 67.1 & $\mathrm{a}$ & 400 & 0.04 & 267 & 0.15 & 0.3 & 1 & 51.5 & 32.2 & 0 & 0 \\
\hline 24 Aug & A & $\mathrm{b}$ & 44 & $\mathrm{~b}$ & 250 & 0.03 & 300 & 0.13 & 0.12 & 1 & 60.2 & 9.6 & 0 & 0 \\
\hline 24 Aug & B & $\mathrm{a}$ & 47.1 & $\mathrm{~b}$ & 200 & 0.03 & 289 & 0.13 & 0.12 & 1 & 153.6 & 8.2 & 0 & 0 \\
\hline 24 Aug & $\mathrm{C}$ & $\mathrm{a}$ & 50.2 & b & 200 & 0.02 & 311 & 0.13 & 0.12 & 1 & 111.4 & 9 & 0 & 0 \\
\hline 24 Aug & $\mathrm{D}$ & $\mathrm{a}$ & 54.1 & $\mathrm{a}$ & 200 & 0.03 & 289 & 0.13 & 0.12 & 1 & 115.4 & 8.1 & 0 & 0 \\
\hline 24 Aug & $\mathrm{E}$ & $\mathrm{a}$ & 57.9 & $\mathrm{a}$ & 200 & 0.03 & 267 & 0.15 & 0.3 & 1 & 87.6 & 7.7 & 0 & 0 \\
\hline 24 Aug & $\mathrm{F}$ & $\mathrm{a}$ & 61.4 & $\mathrm{a}$ & 200 & 0.04 & 289 & 0.15 & 0.3 & 1 & 41.3 & 9.1 & 0 & 0 \\
\hline 24,Aug & G & $\mathrm{a}$ & 64.6 & b & 200 & 0.05 & 244 & 0.15 & 0.3 & 1 & 84.7 & 7.1 & 0 & 0 \\
\hline $24 \mathrm{Aug}$ & $\mathrm{H}$ & $\mathrm{a}$ & 68.4 & b & 200 & 0.05 & 222 & 0.15 & 0.3 & 1 & 67.9 & 2.6 & 0 & 0 \\
\hline 25 Aug & A & $\mathrm{a}$ & 33.4 & $\mathrm{a}$ & 250 & 0.02 & 278 & 0.13 & 0.12 & 1 & 29.2 & 5.9 & 0 & 0 \\
\hline 25 Aug & B & $\mathrm{a}$ & 37.6 & $\mathrm{a}$ & 200 & 0.02 & 278 & 0.13 & 0.12 & 1 & 43.2 & 9.1 & 0 & 0 \\
\hline 25 Aug & $\mathrm{C}$ & $\mathrm{a}$ & 40.8 & $\mathrm{~b}$ & 200 & 0.03 & 311 & 0.13 & 0.12 & 1 & 32.2 & 6.1 & 0 & 0 \\
\hline 25 Aug & $\mathrm{D}$ & $\mathrm{a}$ & 43.9 & $\mathrm{~b}$ & 200 & 0.03 & 267 & 0.13 & 0.12 & 1 & 22.5 & 6.8 & 0 & 0 \\
\hline 25 Aug & $\mathrm{E}$ & $\mathrm{a}$ & 47 & $\mathrm{~b}$ & 200 & 0.04 & 289 & 0.15 & 0.3 & 1 & 31.4 & 6.3 & 0 & 0 \\
\hline 25 Aug & $\mathrm{F}$ & $\mathrm{a}$ & 52 & $\mathrm{~b}$ & 200 & 0.04 & 278 & 0.15 & 0.3 & 1 & 28.3 & 4.1 & 0 & 0 \\
\hline $25 \mathrm{Aug}$ & $\mathrm{G}$ & $\mathrm{a}$ & 54 & $\mathrm{~b}$ & 200 & 0.05 & 244 & 0.15 & 0.3 & 1 & 33.4 & 3.2 & 0 & 0 \\
\hline $25 \mathrm{Aug}$ & $\mathrm{H}$ & $\mathrm{a}$ & 61.2 & $\mathrm{~b}$ & 200 & 0.05 & 211 & 0.15 & 0.3 & 1 & 33.6 & 5.6 & 0 & 0 \\
\hline 26 Aug & A & $\mathrm{a}$ & 37.5 & $\mathrm{~b}$ & 250 & 0.03 & 289 & 0.13 & 0.12 & 1 & 70.2 & 9.2 & 0 & 0 \\
\hline 26 Aug & B & $\mathrm{a}$ & 39.6 & a & 250 & 0.02 & 256 & 0.13 & 0.12 & 1 & 38.3 & 6.8 & 0 & 0 \\
\hline 26 Aug & $\mathrm{C}$ & $\mathrm{a}$ & 41.7 & $\mathrm{~b}$ & 200 & 0.02 & 267 & 0.13 & 0.12 & 1 & 23 & 5.9 & 0 & 0 \\
\hline 26 Aug & $\mathrm{D}$ & $\mathrm{a}$ & 43.8 & $\mathrm{a}$ & 200 & 0.03 & 267 & 0.13 & 0.12 & 1 & 20.3 & 5.2 & 0 & 0 \\
\hline 26 Aug & $\mathrm{E}$ & $\mathrm{a}$ & 45.8 & $\mathrm{~b}$ & 200 & 0.04 & 289 & 0.15 & 0.3 & 1 & 46.6 & 5.2 & 0 & 0 \\
\hline 26 Aug & $\mathrm{F}$ & $\mathrm{a}$ & 49.9 & $\mathrm{~b}$ & 200 & 0.04 & 278 & 0.15 & 0.3 & 1 & 57.7 & 5.5 & 0 & 0 \\
\hline 26 Aug & $\mathrm{G}$ & $\mathrm{a}$ & 51.9 & $\mathrm{~b}$ & 200 & 0.05 & 222 & 0.15 & 0.3 & 1 & 60 & 5.4 & 0 & 0 \\
\hline $26 \mathrm{Aug}$ & $\mathrm{H}$ & $\mathrm{b}$ & 62.6 & $\mathrm{~b}$ & 200 & 0.05 & 211 & 0.15 & 0.3 & 1 & 21.1 & 2.1 & 0 & 0 \\
\hline
\end{tabular}

Note: SNICAR online, http://snow.engin.umich.edu/ 
Acknowledgements. This work was supported by the Global Change Research Program of China (2010CB951401), the National Natural Science Foundation of China (NSFC Grants 41121001), the State Key Laboratory of Cryospheric Sciences, CAS (no. SKLCS-ZZ-2012-01-06), CMA (no. GYHY201106023), the National Science and Technology Pillar Program during the 12th Five-Year Plan Period (2012BAC20B05), the Climate Change Science Foundation of CMA (2013-2014), and the NSFC (Grants 41225002 and 41190081). We would like to thank H. Zhang for processing the albedo data and appreciate the constructive comments of two anonymous referees.

Edited by: X. Xu

\section{References}

Aoki, T., Hori, M., Motoyoshi, H., Tanikawa, T., Hachikubo, A., Sugiura, K., Yasunari, T. J., Storvold, R., Eide, H. A., and Stamnes, K.: ADEOS-II/GLI snow/ice products-Part II: Validation results using GLI and MODIS data, Remote Sens. Environ., 111, 274-290, doi:10.1016/j.rse.2007.02.035, 2007.

Aoki, T., Kuchiki, K., Niwano, M., Kodama, Y., Hosaka, M., and Tanaka, T.: Physically based snow albedo model for calculating broadband albedos and the solar heating profile in snowpack for general circulation models, J. Geophys. Res.-Atmos. (19842012), 116, D11114, doi:10.1029/2010JD015507, 2011.

Benn, D. I. and Evans, D. J.: Glaciers and glaciation, Hodder Education, 22-49, 2010.

Bond, T., Doherty, S., Fahey, D., Forster, P., Berntsen, T., DeAngelo, B., Flanner, M., Ghan, S., Kärcher, B., and Koch, D.: Bounding the role of black carbon in the climate system: A scientific assessment, J. Geophys. Res.-Atmos., 118, 5380-5552, doi:10.1002/jgrd.50171, 2013.

Cao, J., Tie, X., Xu, B., Zhao, Z., Zhu, C., Li, G., and Liu, S.: Measuring and modeling black carbon (BC) contamination in the SE Tibetan Plateau, J. Atmos. Chem., 67, 45-60, 2010.

Chow, J. C., Watson, J. G., Pritchett, L. C., Pierson, W. R., Frazier, C. A., and Purcell, R. G.: The DRI thermal/optical reflectance carbon analysis system: description, evaluation and applications in US air quality studies, Atmos. Environ. A-Gen., 27, 11851201, 1993.

Cong, Z., Kang, S., Gao, S., Zhang, Y., Li, Q., and Kawamura, K.: Historical trends of atmospheric black carbon on Tibetan Plateau as reconstructed from a 150-year lake sediment record, Environ. Sci. Technol., 47, 2579-2586, 2013.

Dou, T., Xiao, C., Shindell, D. T., Liu, J., Eleftheriadis, K., Ming, J., and Qin, D.: The distribution of snow black carbon observed in the Arctic and compared to the GISS-PUCCINI model, Atmos. Chem. Phys., 12, 7995-8007, doi:10.5194/acp-12-79952012, 2012.

Farmer, G. T. and Cook, J.: Earth's Albedo, Radiative Forcing and Climate Change, in: Climate Change Science: A Modern Synthesis, Springer, 217-229, 2013.

Fitzgerald, W. F.: Clean hands, dirty hands: Clair Patterson and the aquatic biogeochemistry of mercury, Clean Hands, Clair Patterson's Crusade Against Environmental Lead Contamination, 119137, 1999.
Flanner, M. G.: Arctic climate sensitivity to local black carbon, J. Geophys. Res.-Atmos., 118, 1840-1851, doi:10.1002/jgrd.50176, 2013.

Flanner, M. G., Zender, C. S., Randerson, J. T., and Rasch, P. J.: Present-day climate forcing and response from black carbon in snow, J. Geophys. Res, 112, D11202, doi:10.1029/2006JD008003, 2007.

Fujita, K.: Effect of dust event timing on glacier runoff: sensitivity analysis for a Tibetan glacier, Hydrol. Process., 21, 2892-2896, 2007.

Ginot, P., Dumont, M., Lim, S., Patris, N., Taupin, J.-D., Wagnon, P., Gilbert, A., Arnaud, Y., Marinoni, A., Bonasoni, P., and Laj, P.: A 10 year record of black carbon and dust from a Mera Peak ice core (Nepal): variability and potential impact on melting of Himalayan glaciers, The Cryosphere, 8, 1479-1496, doi:10.5194/tc-8-1479-2014, 2014.

Hadley, O. L. and Kirchstetter, T. W.: Black-carbon reduction of snow albedo, Nature Climate Change, 2, 437-440, 2012.

Hall, D. K., Riggs, G. A., and Salomonson, V. V.: MODIS/Terra Snow Cover Daily L3 Global 500m Grid V005, January 2001 to December 2010, Boulder, Colorado USA: National Snow and Ice Data Centre, Digital media (updated daily), 2006.

Immerzeel, W. W., van Beek, L. P., and Bierkens, M. F.: Climate change will affect the Asian water towers, Science, 328, 13821385, 2010.

IPCC, C. C.: The Physical Science Basis, Contribution of Working Group I to the Fourth Assessment Report of the Intergovernmental Panel on Climate Change, Cambridge University Press, Cambridge, United Kingdom and New York, NY, USA, 996, 2007.

Kang, S., Wake, C. P., Dahe, Q., Mayewski, P. A., and Tandong, Y.: Monsoon and dust signals recorded in Dasuopu glacier, Tibetan Plateau, J. Glaciol., 46, 222-226, 2000.

Kang, S., Xu, Y., You, Q., Flügel, W. A., Pepin, N., and Yao, T.: Review of climate and cryospheric change in the Tibetan Plateau, Environ. Res. Lett., 5, 015101, doi:10.1088/17489326/5/1/015101, 2010.

Kaspari, S., Painter, T. H., Gysel, M., Skiles, S. M., and Schwikowski, M.: Seasonal and elevational variations of black carbon and dust in snow and ice in the Solu-Khumbu, Nepal and estimated radiative forcings, Atmos. Chem. Phys., 14, 80898103, doi:10.5194/acp-14-8089-2014, 2014.

Kopacz, M., Mauzerall, D. L., Wang, J., Leibensperger, E. M., Henze, D. K., and Singh, K.: Origin and radiative forcing of black carbon transported to the Himalayas and Tibetan Plateau, Atmos. Chem. Phys., 11, 2837-2852, doi:10.5194/acp-11-28372011, 2011.

Lau, W., Kim, M., Kim, K., and W. Lee: Enhanced surface warming and accelerated snow melt in the Himalayas and Tibetan Plateau induced by absorbing aerosols, Environ. Res. Lett., 5, 025204, 2010.

Lhermitte, S., Greuell, W., van Meijgaard, E., van Oss, R., van den Broeke, M., and van de Berg, W.: Greenland ice sheet surface albedo: trends in surface properties (2000-2011), EGU General Assembly Conference Abstracts, 2012.

Ming, J., Cachier, H., Xiao, C., Qin, D., Kang, S., Hou, S., and $\mathrm{Xu}$, J.: Black carbon record based on a shallow Himalayan ice core and its climatic implications, Atmos. Chem. Phys., 8, 13431352, doi:10.5194/acp-8-1343-2008, 2008. 
Ming, J., Xiao, C., Du, Z., and Flanner, M. G.: Black Carbon in snow/ice of west China and its radiave forcing, Advances in Climate Change Research, 92, 114-123, 2009a (in Chinese with English abstract).

Ming, J., Xiao, C. D., Cachier, H., Qin, D. H., Qin, X., Li, Z. Q., and $\mathrm{Pu}, \mathrm{J}$. C.: Black Carbon (BC) in the snow of glaciers in west China and its potential effects on albedos, Atmos. Res., 92, 114123, 2009b.

Ming, J., Xiao, C., Sun, J., Kang, S., and Bonasoni, P.: Carbonaceous particles in the atmosphere and precipitation of the Nam Co region, central Tibet, J. Environ. Sci., 22, 1748-1756, 2010.

Ming, J., Du, Z., Xiao, C., Xu, X., and Zhang, D.: Darkening of the mid-Himalaya glaciers since 2000 and the potential causes, Environ. Res. Lett., 7, 014021, doi:10.1088/1748-9326/7/1/014021, 2012.

Ming, J., Wang, P., Zhao, S., and Chen, P.: Disturbance of lightabsorbing aerosols on the albedo in a winter snowpack of Central Tibet, J. Environ. Sci., 25, 1601-1607, 2013a.

Ming, J., Xiao, C., Du, Z., and Yang, X.: An Overview of Black Carbon Deposition in High Asia Glaciers and its Impacts on Radiation Balance, Adv. Water Resour., 55, 80-87, 2013 b.

Mote, P. W., Parson, E. A., Hamlet, A. F., Keeton, W. S., Lettenmaier, D., Mantua, N., Miles, E. L., Peterson, D. W., Peterson, D. L., and Slaughter, R.: Preparing for climatic change: the water, salmon, and forests of the Pacific Northwest, Climatic Change, 61, 45-88, 2003.

Oki, T. and Kanae, S.: Global hydrological cycles and world water resources, Science, 313, 1068-1072, 2006.

Painter, T. H., Barrett, A. P., Landry, C. C., Neff, J. C., Cassidy, M. P., Lawrence, C. R., McBride, K. E., and Farmer, G. L.: Impact of disturbed desert soils on duration of mountain snow cover, Geophys. Res. Lett., 34, L12502, doi:10.1029/2007GL030284, 2007.

Painter, T. H., Skiles, S. M., Deems, J. S., Bryant, A. C., and Landry, C. C.: Dust radiative forcing in snow of the Upper Colorado River Basin: 1. A 6 year record of energy balance, radiation, and dust concentrations, Water Resour. Res., 48, W07521, doi:10.1029/2012WR011985, 2012.

Qian, Y., Flanner, M. G., Leung, L. R., and Wang, W.: Sensitivity studies on the impacts of Tibetan Plateau snowpack pollution on the Asian hydrological cycle and monsoon climate, Atmos. Chem. Phys., 11, 1929-1948, doi:10.5194/acp-11-19292011, 2011.

Riggs, G. and Hall, D.: MODIS snow and ice products, and their assessment and applications, in: Land Remote Sensing and Global Environmental Change, Springer New York, 681-707, 2011.

Şorman, A. Ü., Akyürek, Z., Şensoy, A., Şorman, A. A., and Tekeli, A. E.: Commentary on comparison of MODIS snow cover and albedo products with ground observations over the mountainous terrain of Turkey, Hydrol. Earth Syst. Sci., 11, 1353-1360, doi:10.5194/hess-11-1353-2007, 2007.

Stroeve, J. C., Box, J. E., and Haran, T.: Evaluation of the MODIS (MOD10A1) daily snow albedo product over the Greenland ice sheet, Remote Sens. Environ., 105, 155-171, 2006.

Sugden, D. E. and John, B. S.: Glaciers and landscape: a geomorphological approach, Edward Arnold London, 1976.
Tekeli, A. E., Şensoy, A., Şorman, A., Akyürek, Z., and Şorman, Ü.: Accuracy assessment of MODIS daily snow albedo retrievals with in situ measurements in Karasu basin, Turkey, Hydrol. Process., 20, 705-721, 2006.

Wang, J., Ye, B., Cui, Y., He, X., and Yang, G.: Spatial and temporal variations of albedo on nine glaciers in western China from 2000 to 2011, Hydrol. Process., 28, 3454-3465, 2014.

Wang, M., Xu, B., Cao, J., Tie, X., Wang, H., Zhang, R., Qian, Y., Rasch, P. J., Zhao, S., Wu, G., Zhao, H., Joswiak, D. R., Li, J., and Xie, Y.: Carbonaceous aerosols recorded in a Southeastern Tibetan glacier: variations, sources and radiative forcing, Atmos. Chem. Phys. Discuss., 14, 19719-19746, doi:10.5194/acpd-1419719-2014, 2014.

Wang, Q., Jacob, D. J., Fisher, J. A., Mao, J., Leibensperger, E. M., Carouge, C. C., Le Sager, P., Kondo, Y., Jimenez, J. L., Cubison, M. J., and Doherty, S. J.: Sources of carbonaceous aerosols and deposited black carbon in the Arctic in winter-spring: implications for radiative forcing, Atmos. Chem. Phys., 11, 12453 12473, doi:10.5194/acp-11-12453-2011, 2011.

Wang, J., He, X., Ye, B., and Yang, G.: Variations of Albedo on the Dongkemadi Glacier, Tanggula Range, Journal of Glaciology and Geocryology, 34, 21-28, 2012 (in Chinese with English abstract).

Warren, S. G.: Can black carbon in snow be detected by remote sensing?, J. Geophys. Res.-Atmos., 118, 779-786, 2013.

Warren, S. G. and Wiscombe, W. J.: A model for the spectral albedo of snow. II: Snow containing atmospheric aerosols, J. Atmos. Sci., 37, 2734-2745, 1980.

Wiscombe, W. J. and Warren, S. G.: A model for the spectral albedo of snow. I: Pure snow, J. Atmos. Sci., 37, 2712-2733, 1980.

Xu, B., Yao, T., Liu, X., and Wang, N.: Elemental and organic carbon measurements with a two-step heating gas chromatography system in snow samples from the Tibetan Plateau, Ann. Glaciol., 43, 257-262, 2006.

Xu, B., Cao, J., Hansen, J., Yao, T., Joswia, D. R., Wang, N., Wu, G., Wang, M., Zhao, H., and Yang, W.: Black soot and the survival of Tibetan glaciers, Proc. Natl. Acad. Sci., 106, 22114-22118, 2009a.

Xu, B., Wang, M., Joswiak, D. R., Cao, J. J., Yao, T. D., Wu, G. J., Yang, W., and Zhao, H. B.: Deposition of anthropogenic aerosols in a southeastern Tibetan glacier, J. Geophys. Res., 114, D17209, doi:10.1029/2008JD011510, 2009b.

Xu, B., Cao, J., Joswiak, D. R., Liu, X., Zhao, H., and He, J.: Postdepositional enrichment of black soot in snow-pack and accelerated melting of Tibetan glaciers, Environ. Res. Lett., 7, 014022, doi:10.1088/1748-9326/7/1/014022, 2012.

Yao, T., Thompson, L., Yang, W., Yu, W., Gao, Y., Guo, X., Yang, X., Duan, K., Zhao, H., and Xu, B.: Different glacier status with atmospheric circulations in Tibetan Plateau and surroundings, Nature Climate Change, 2, 663-667, 2012.

Zhang, G., Kang, S., Fujita, K., Huintjes, E., Xu, J., Yamazaki, T., Haginoya, S., Wei, Y., Scherer, D., and Schneider, C.: Energy and mass balance of Zhadang glacier surface, central Tibetan Plateau, J. Glaciol., 59, 137-148, 2013.

Zhao, S., Ming, J., Sun, J., and Xiao, C.: Observation of carbonaceous aerosols during 2006-2009 in Nyainqentanglha Mountains and the implications for glaciers, Environ. Sci. Pollut. Re., 20, 5827-5838, 2013. 
Zhou, G., Yao, T., Kang, S., Pu, J., Tian, L., and Yang, W.: Mass balance of the Zhadang glacier in the central Tibetan Plateau, Journal of Glaciology and Geocryology, 29, 360-365, 2007 (in Chinese with English abstract). 